\title{
Formative E-Assessment: A Qualitative Study Based on Master's Degrees
}

\author{
Paz Prendes-Espinosa ${ }^{1}$, Pedro A. García-Tudela ${ }^{1} \&$ Isabel Gutiérrez-Porlán $^{1}$ \\ ${ }^{1}$ Faculty of Education, University of Murcia, Spain \\ Correspondence: Paz Prendes-Espinosa, Faculty of Education, University of Murcia, 30100 Murcia, Spain. \\ E-mail: pazprend@um.es
}

Received: June 11, 2021

Accepted: August 12, 2021

Online Published: February 25, 2022

doi:10.5539/ies.v15n2p1

URL: https://doi.org/10.5539/ies.v15n2p1

\begin{abstract}
Formative assessment is a strategy that optimizes the learning process at any educational level, however its use is not very frequent as literature revision shows. In this paper, we analyse the use of formative assessment in online postgraduate studies (masters) in Spanish universities. Our sample was 31 online master's degrees coordinators and we analyse the results obtained from a questionnaire with open questions using NVIVO software. Through qualitative analysis of the information supported by cross-queries of codes and attributes, we have considered formative assessment according to fields of knowledge, the type of digital tools used and the main difficulties identified. In this type of online masters, our data show that most of the teachers use this type of formative e-assessment to provide feedback to their students and as part of the final marks of the courses, too. So these results are relevant to understand the E-assessment strategies for master's degrees. Finally, the main limitation of the study is the fact that it uses a sample limited to the geographical context of Spain. Nevertheless, these data are representative of E-assessment in Spanish master's degrees and may be of interest for future research, for comparative studies in other contexts and even with face-to-face or blended-learning master's degrees.
\end{abstract}

Keywords: formative assessment, E-assessment, feedback, E-learning, online, postgraduate, higher education

\section{Introduction}

Assessment and feedback are fundamental aspects of any teaching-learning process regardless of its modality: virtual, blended or face-to-face (Mimirinis, 2019; Wuisan \& Wibawa, 2019). Moreover we can use conventional methods, or electronic, or combined assessment using both of them (Hasani et al., 2021). However, there is a general tendency to link the e-evaluation with the completion of digital final questionnaires to measure the scope of the achievements (Sánchez-Vera et al., 2013).

Generally, any educational context should assess from a multi-perspective, since different teaching methodologies are also often used. In other words, any e-assessment process should contemplate different strategies based on the e-formative assessment, e-peer assessment and e-self assessment (Babo et al., 2021; Lu \& Law, 2012; Mosqueda, 2018), not only summative assessment in the end of the courses.

Through this work, we intend to reflect on the importance of other e-assessment strategies -not only the summative- to facilitate the effective learning of any student in a virtual environment. Specifically, we will explore the e-formative assessment, whose main notable element is giving feedback to students. According to Zhu et al. (2021), the feedback can benefit the learning, the engagement, the positive emotions and the disposition toward learning of master's degrees students.

In this qualitative research, we applied a structured interview to coordinators of postgraduate studies from different public and private universities from Spain and whose learning modality is virtual (online masters' degrees). The development of the interviews was online and structured around different predefined questions to extract meaningful information related to our research question and objectives. The analysis of the qualitative data was carried out with NVivo software, which facilitated the coding and creation of nodes. Mainly, by applying the cross searches between codes and attributes, we found interesting results about the used methodologies to implement E-formative assessment at university, digital tools to give feedback, difficulties for teachers and students and other relevant information related to the topic of this paper. 


\section{Review of Related Literature}

Over time, online and blended learning are becoming two models of great interest when compared to traditional face-to-face teaching, and despite their possibilities, they also highlight different concerns that must be addressed to gain an optimal educational experience (Chandrasekaran et al., 2016; Zwelijongile, 2015). Concerns are generally associated with the assessment process (Cabero, 2017; Sharma \& Karforma, 2012), although they may also exist in any other of the substantial elements of an educational process (González-Sanmamed et al., 2018).

\subsection{About E-Assessment}

Focusing on assessment, and specifically on electronic assessment (E-assessment), this emerges as an alternative to overcoming the deficiencies of traditional pencil and paper assessment modes, so that E-assessment is based on the use of digital tools which assess the theoretical and practical knowledge of any student (Azevedo \& Azevedo, 2018). Furthermore, in virtual environments, assessment must be one of the most significant elements of educational practice, since students tend to demand greater attention due to the lack of contact with the teacher (González, 2020).

Despite this virtuality, E-assessment not only has to be developed in online teaching models but can also be present in physical contexts and thus enrich the educational experience, since E-assessment should not be based only on online tests (Sánchez-Vera et al., 2013). According to Babo et al. (2021, p. 69), "with individuals' motivation for implementing new tools or improving existing ones, to support unbiased assessments, concepts like usability, user experience, assessment and the relation between them are being studied". Furthermore, students tend to better assess the evaluation modes that are developed through technology (Bahati et al., 2019). Therefore, to guarantee the implementation of E-assessment without the need for technology-equipped rooms, the "Bring Your Own Device" (BYOD) strategy is often recommended (Küppers \& Schroeder, 2016).

Leaving aside this dimension of digital assessment in physical contexts, we will explore e-assessment in virtual contexts, which has very characteristic benefits: "efficiently managing and streamlining the assessment process; facilitating dialogue and student engagement; enhancing student learning and developing (digital) identity and the community" (Mimirinis, 2019, p. 6). In general, it should be noted that E-assessment provides benefits in lectures, and for students and institutions (Wuisan \& Wibawa, 2019).

\subsection{Types of E-Assessment}

The benefits outlined in the previous paragraph do not only apply to digital assessment in general. The distinctive aspects of each type of assessment must be taken into account (Prendes et al., 2021). Four different E-assessment types can be distinguished: summative E-assessment as the addition of the results obtained at the end of lessons, courses or projects (Sewell et al., 2010) through digital tools such as forums, quizzes, etc.; E-self assessment consists of a reflective process which identifies strengths and weaknesses concerning the achievement of objectives using online questionnaires (Mosqueda, 2018) or other alternatives such as E-portfolios, or digital apps like Socrative. E-peer assessment is the digital feedback that is generated among students who define themselves as assessors or assesses (Lu \& Law, 2012) and is usually developed through videoconference tools, social networks, and so on. The last type of electronic assessment is formative E-assessment, the type of assessment that is examined in this article.

\subsection{Formative E-Assessment}

Generally, formative assessment is defined as the feedback that teachers give to students to improve their educational experience and to make them more responsible for their learning (Irons, 2008). More specifically, Colmenares (2012) states that formative E-assessment is how the teacher identifies the weaknesses and strengths that each student has which gives them self-awareness through chats, forums, blogs or other digital tools. In this way students can act proactively to meet their academic needs.

Colmenares (2012) also demonstrates that formative assessment is an opportunity in physical environments due to the spontaneous interaction that is generated. However, he states that in a virtual environment this could also be maintained as long as there is a self-instructional process. In other words, formative E-assessment should have a self-evaluating aspect, so that the teacher adopts the role of guide and the students of protagonists.

The way to carry out a formative E-assessment depends on the different variables that condition the procedure (discipline, number of students, and available digital tools.). Certain authors (Bahati et al., 2019; Vonderwell \& Boboc, 2013) talk about some of the most widely used techniques: role-play, the minute paper, reflection paper, hook questions, things to keep in mind, questions walls, online knowledge survey, and reflective electronic journals, and so on. However, all of them have to adapt to educational reality to avoid inconveniences such as the student not knowing what to do with the comments; not valuing feedback, as they only care about their grades; or 
using feedback differently than expected (Irons, 2008).

Sometimes it is not possible to take advantage of formative E-assessment, as explained in the previous paragraph. However, from the perspective of a university student, formative E-assessment presents a series of possibilities. It can monitor their progress, motivate them to continue achieving academic objectives, improve understanding and benefit active participation (McCallum \& Milner, 2020).

Throughout this examination, formative E-assessment is shown to be a digital version of physical formative assessment, in which teacher-student interaction is essential. However, within a virtual environment there is also a line that links learning analytics with E-assessment and more specifically, with formative E-assessment. We can see that learning analytics allow the monitoring of students through the data collected by using a digital learning environment with interactive resources that facilitate automatic assessment (Barana et al., 2019).

\section{Research Question and Research Objectives}

We intend to reflect on the importance of other types of E-assessment -as distinct from the most commonly used summative assessment- to facilitate effective learning by any student in a virtual environment. Specifically, we will explore E-formative assessment, whose most notable element is feedback as we have explained (González, 2020; Zhu et al., 2021). Our research question is: how is E-formative assessment used in online master's degrees in Spain? Our main research objectives are:

1) To analyse the formative strategies used to assess students in Spanish online master's degrees.

2) To identify digital tools used for the development of E-formative assessment strategies in Spanish online master's degrees.

3) To describe the thoughts of different coordinators of online master's degrees about E-formative assessment based on their experience.

\section{Method}

\subsection{Research Design}

This research is focused on a qualitative approach. According to McMillan and Schumacher (2005), qualitative methods intend to analyse and describe the research object using the subjective interpretation of the participants. Our research fits into this frame, because we have collected the information from the coordinators of online master's degrees in Spain so we can use their knowledge to describe the use of these assessment strategies. We have used an interview to collect information and the coordinators of the online master's degrees as population.

\subsection{Phases and Proceedings}

The first step was the identification of the participants. We needed to know all the online master's degrees in Spain, so we searched for the list of public and private universities on the page of the Ministry of Education and then we searched on every institutional web page for specific information about online master's degrees $(n=141)$ in universities. Finally, we searched for the names and emails of coordinators.

Once we had this completed list of degrees with their coordinators, we classified the results using three criteria: field of knowledge, area of knowledge and universities. To select the sample, we chose a proportional stratified sampling using these criteria and we sent the information about the research and the interview by email. We found the usual problem of people who did not answer, people who did not want to participate and people who did not want to answer the interview by videoconference. We sent messages by email every three days, trying to complete the desired sample. Finally, we had to use all the contacts in the list so we can say that we wrote to coordinators of all the online master's degrees list. In the field of knowledge of Sciences, we did not receive any answer, although we sent the emails to coordinators twice. To solve the problem of coordinators who did not want to connect by videoconference, we used the email as a communication tool and we sent the written questions.

After two months, we closed the proceeding to collect data and the third phase was the analysis of collected data with NVivo (release 1.3 version).

\subsection{Sampling Procedures}

We have applied a proportional stratified sampling based on these criteria: representativity of every field of knowledge, of all areas of knowledge, of different universities and gender of coordinators. Once the strata were defined, one person from each group was randomly taken until the sample was completed.

The initial population of all online master's degrees was 141, but we excluded three of them because they are not genuine online studies as they were online because of the Covid-19 pandemic. Therefore, we finally included 138 studies. We estimated a minimum of $10 \%$ in every group from a total of 14 master's degrees. However, we have 31 
answers (Table 1).

Table 1. Distribution of the sample according to fields of knowledge

\begin{tabular}{|c|c|c|c|c|c|c|}
\hline $\begin{array}{c}\text { Field of } \\
\text { knowledge }\end{array}$ & $\begin{array}{l}\text { No. of online } \\
\text { masters }\end{array}$ & $\begin{array}{c}\text { Online } \\
\text { COVID-19 }\end{array}$ & $\begin{array}{l}\text { Estimated } \\
\text { sample }\end{array}$ & $\begin{array}{c}\text { Final } \\
\text { sample }\end{array}$ & $\begin{array}{l}\% \text { in relation to sample } \\
\qquad(\mathrm{N}=31)\end{array}$ & $\begin{array}{l}\% \text { in relation to population } \\
\qquad(\mathrm{N}=138)\end{array}$ \\
\hline $\begin{array}{l}\text { Social-Legal } \\
\text { Sciences }\end{array}$ & 65 & 2 & 6 & 16 & $51.6 \%$ & $11.6 \%$ \\
\hline AA-HUM & 28 & 0 & 3 & 5 & $16.1 \%$ & $3.6 \%$ \\
\hline ENG-ARCH & 24 & 0 & 2 & 5 & $16.1 \%$ & $3.6 \%$ \\
\hline Health Sciences & 16 & 1 & 2 & 5 & $16.1 \%$ & $3.6 \%$ \\
\hline Sciences & 5 & 0 & 1 & 0 & $0 \%$ & $0 \%$ \\
\hline Total & 138 & 0 & 14 & 31 & $100 \%$ & $22.4 \%$ \\
\hline
\end{tabular}

The final sample represents $22.44 \%$ of the population and it should be noted that no response has been obtained from the coordinators of the master's degrees in the field of Sciences, despite having repeatedly sent the email in this stratum, as we have already explained.

\subsection{Participant Characteristics}

The distribution of the sample according to sex is balanced (17 men and 14 women) and most of them have specific training in virtual education $(n=23)$ and most of them $(n=27)$ also have teaching experience in virtual education. Specifically, the majority have between one and five years of experience $(n=11)$ and only 4 cases do not teach subjects, but only coordinate the master's ( 2 in Social and Legal Sciences and 2 in Health Sciences).

In terms of experience as coordinators, a large number of cases have been coordinating the master for between one and five years $(\mathrm{n}=17)$ and 13 respondents have been doing so for more than six years $(\mathrm{n}=6$ between six and ten years and $\mathrm{n}=7$ more than ten years).

Taking into account Figure 1, the interval between one and five years stands out both in teaching experience and in experience as coordinator. However, when adding the sample corresponding to more than six years (between six and ten years and more than ten years) there are 16 cases with six or more years of experience.

From these data, it can be stated that the majority of the sample are new coordinators $(n=17)$ since they have between one and five years of experience. However, the majority of the teaching-related sample has more experience, since there are 16 cases with six or more years of experience.

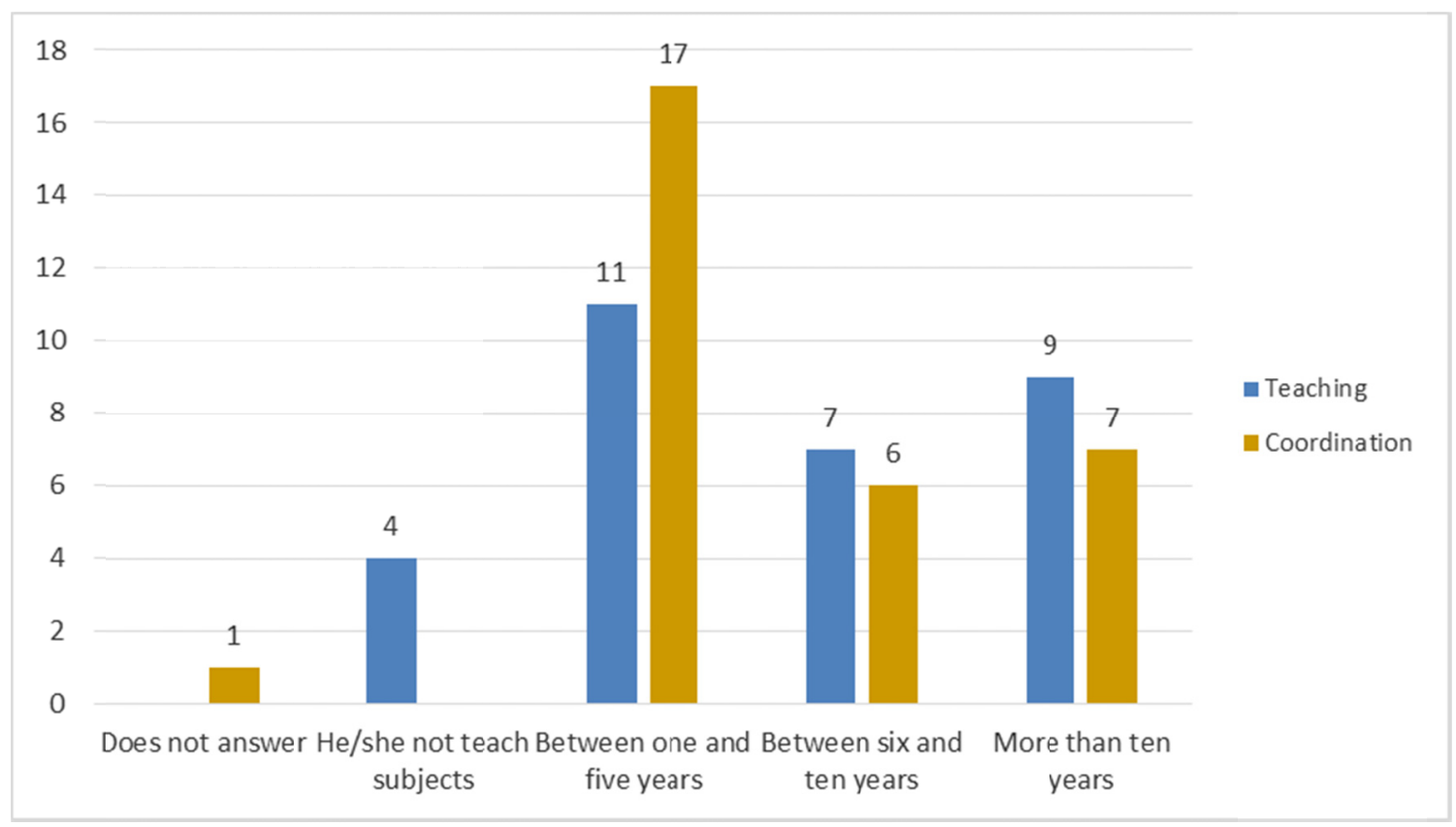

Figure 1. Teaching and coordination experience of the sample 


\subsection{Research Instrument}

Taking as a starting point the objectives mentioned above, we designed the interview following Alvira (2011) in these phases: a list of questions relative to every topic; question design; structure (order, format); first draft; review by the study team; and finally, validation.

We decided to design a structured interview with open questions. The script consisted of 4 socio-demographic questions plus 13 open questions classified in three types according to McMillan and Schumacher (2005): experience, knowledge and opinion. Moreover, we designed questions relative to two topics: E-assessment strategies and telematic tools used by teachers. It should be noted that at the beginning of the questionnaire a description of formative assessment was added to avoid possible confusion or misinterpretations of the concept since it has been identified that in some cases a formative evaluation has been applied, but has not been identified as such (Aleyaasin, 2018).

Expert judgement was chosen for the validation of the instrument. For this purpose, we selected five experts from the field of Educational Technology with experience both in training and E-assessment. An instruction sheet then was prepared (Delphi method), in which the following aspects were considered for validation, following the proposals of Escobar-Pérez and Cuervo-Martínez (2008): coherence, relevance, clarity and sufficiency of each of the items.

When all the information was collected, a quantitative analysis of the results was carried out, obtaining the average of each of the sections analysed. According to Crocker and Algina (1986), it was decided to eliminate the questions with a score lower than two.

\subsection{Data Analysis}

We have carried out the data analysis with NVivo (release 1.3 version). First, the 31 cases have been classified according to 5 attributes that respond to the sociodemographic questions of the questionnaire. These have been (1) sex, (2) specific training in virtual teaching, (3) experience teaching virtual teaching, (4) field of knowledge of the master and (5) experience coordinating the master.

Then, for each question a free code has been generated, which has different codes associated with it according to the references that have been marked in each of the cases analysed. From this coding process, the results have been analysed both independently and through cross-queries that relate to the results of each question with the attributes mentioned in the previous paragraph.

To analyse the results and extract the most relevant results, different graphs have been used, such as heat, radar, stacked bars and maps. However, the results below show those of greater value according to the objectives set.

\section{Results}

Firstly, we found that not all master's degrees see formative evaluation as a possibility since 6 coordinators (19.3\%) affirm that their master's degree only takes into account the summative or final assessment. On the other hand, a vast majority represented by 24 cases $(77.4 \%)$ do confirm that formative assessment is a reality throughout the master's degree. As an isolated case (3.2\%), there is a master's degree in the field of Social and Legal Sciences that allows its students to select the type of assessment they prefer to have throughout the course. Next, Figure 2 shows a stacked bar graph that shows the responses according to the coordinator's fields of knowledge. As stated, 3 codes have been generated that group together the previously mentioned information. 


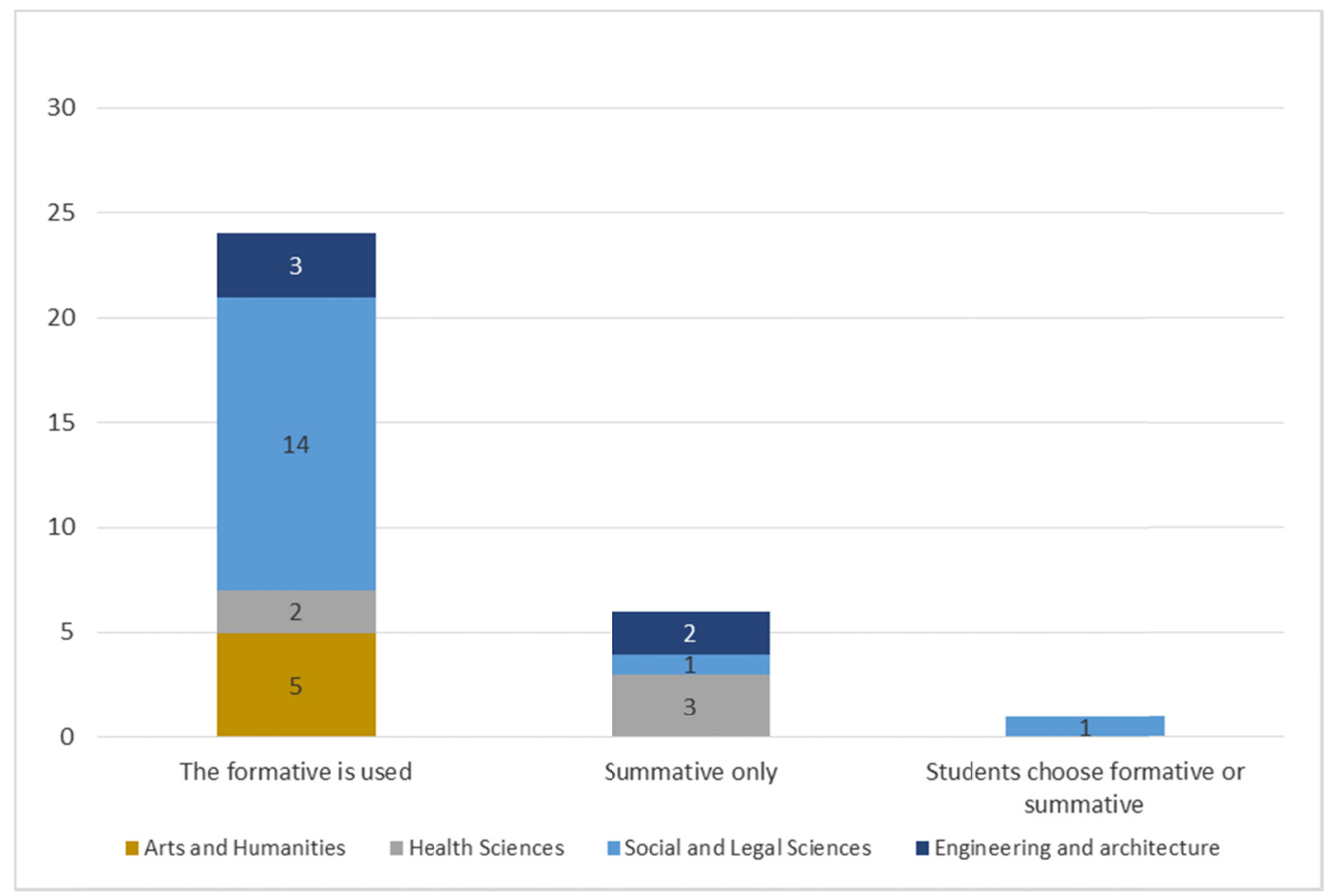

Figure 2. Type of evaluation according to fields of knowledge

Relevant information can be extracted from the results shown in the graph since Health Sciences and Engineering and Architecture are the two fields that mostly choose to assess only in a summative way, since 3 out of 5 master's degrees in Health Sciences, and 2 out of 5 master's degrees in Engineering and Architecture choose this option. On the other hand, it should be noted that Arts and Humanities is the only field of knowledge in which all master's degrees involve a formative assessment.

After analysing the results obtained from the first question on the type of assessment implemented, it is necessary to recalculate the final sample, since it is not appropriate to use the coordinators who have indicated that their master's courses only use summative assessment. This is mainly because the rest of the questionnaire delves into different aspects of the formative assessment. Due to the aforementioned fact, we can see that the final sample, that is the one taken into account for the rest of the questions, is 25 cases (14 men [56\%] and 11 women [44\%]) distributed according to fields of knowledge as presented in Table 2.

Table 2. Definitive sample according to fields of knowledge

\begin{tabular}{cccccc}
\hline Social-Legal Sciences & AA-HUM & ENG-ARCH & Health Sciences & Sciences & Total \\
\hline $15(60 \%)$ & $5(20 \%)$ & $3(12 \%)$ & $2(8 \%)$ & $0(0 \%)$ & $25(100 \%)$ \\
\hline
\end{tabular}

When examining the frequency at which each master's degree uses formative assessment, it is observed that $64 \%$ $(n=16)$ of all master's degrees use formative assessment with their students in all subjects of the study program. On the contrary, not a single case of master's degrees in the field of Engineering and Architecture uses formative assessment in all its subjects, but mostly depends on the choice of the teacher, $(\mathrm{n}=2[66.7 \%])$ or is only considered in half of the subjects $(\mathrm{n}=1[33.3 \%])$.

When asking if the formative assessment represents a percentage of the final grade for the subjects, the analysis of the information obtained shows that $88 \%(\mathrm{n}=22)$ of the coordinators confirm that the formative evaluation does have value in the final grade. In other words, formative assessment is not only used as a resource to offer feedback and to improve the learning process but also represents a percentage of the final grade obtained by each student in the subject.

The ways of giving feedback to students are very diverse, since the analysis of this question has shown 47 references distributed between 16 codes. Table 3 shows the codes that appear most frequently in the responses. For 
the most part, to facilitate feedback, written and asynchronous communication is used, although the code "different digital tools of the official virtual platform" could include other different options such as videoconferences. However, we see that the majority of responses specify forums, messages and reviews of tasks that students are submitting.

Table 3. Most used digital tools to give feedback

\begin{tabular}{lc}
\hline Codes & References \\
\hline "Forums" & $8(17 \%)$ \\
"Different digital tools of the official virtual platform" & $8(17 \%)$ \\
"Through the students' tasks" & $8(17 \%)$ \\
"Electronic messaging" & $7(14.9 \%)$ \\
\hline
\end{tabular}

An alternative for complementing the formative assessment is the statistics and access data or data on the use of resources that the vast majority of platforms offer. However, half of the sample $(n=12$ [48\%]) confirmed that the teachers in the master's degrees do not consider such statistical information. In the same sense, 17 coordinators $(68 \%)$ do not consult the statistics of the virtual platform used either. Only 6 coordinators $(24 \%)$ take this information into account when identifying the main problems of the students.

When analysing the results of a cross-consultation between the years of experience coordinating the master's degree and the statistics into account, an interesting result is obtained. As shown in the radar graph (Figure 3), there is a positive tendency to use the statistical information derived from the formative assessment when there are more years of experience coordinating the master's degree. Above all, this fact is shown in cases with between six and ten years of experience, although also, but to a lesser extent, in those who have been coordinating the master for more than ten years. Therefore, not considering the statistics is mainly associated with coordinators who have less experience. That is between one and five years.

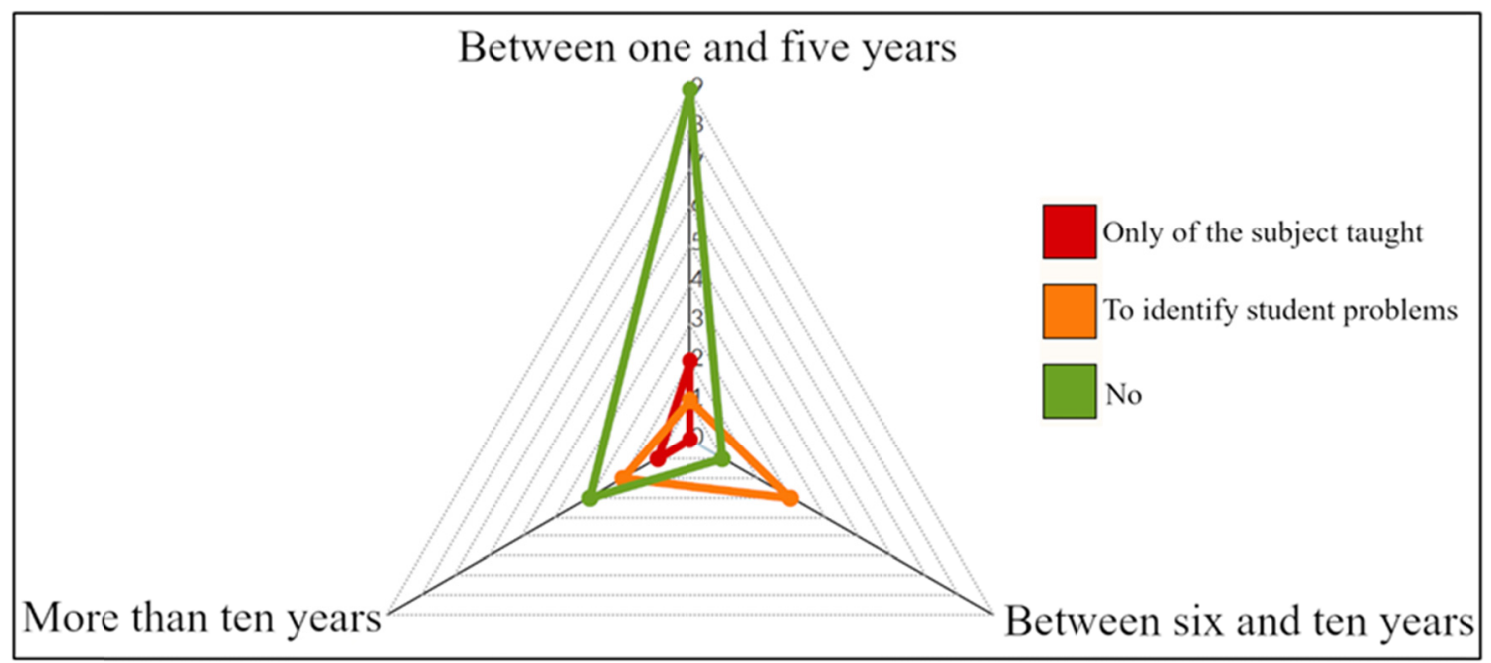

Figure 3. Cross-query radar chart: coordination experience and review of the formative evaluation statistics

The question related to the benefits of formative assessment has also been amongst those that have generated the most information since 42 references and 12 codes have been obtained. However, two responses appear more frequently: formative assessment "improves the teaching and learning process" $(31.7 \%$ [ $=13])$ and it "allows a better monitoring of the learning process" $(24.4 \%[n=10])$. Likewise, the second category of benefits observed by the coordinators is represented by the following 4 codes, each of them having 3 associated references $(7.3 \%$ each code): "it favours a closer relationship between teachers and students", "it improves autonomy and self-regulation of learning", "allows the adaptation of teaching resources and methodologies" and finally, "satisfaction and motivation".

On the contrary, concerning the difficulties that formative assessment can present to teachers and students, the data 
that stands out is that 15 references (46.9\%) of difficulties for teachers are associated with the code of "temporary dedication". Similarly, 10 references about problems for students belong to the code "greater dedication and perseverance" (55.6\%). Despite the other difficulties shown in Figure 4 ("teacher training", "student teacher ratio", etc.), the time that should be devoted to formative assessment is the main cause of concern for the coordinators and they point this out as the main difficulty. In addition to the fact that time is the greatest difficulty indicated (both about the dedication of the teaching staff and about the time involved on the part of the students), another significant result can be extracted from this comparison. Some coordinators $(n=3[16.7 \%])$ think that students have fewer difficulties or problems than teachers when facing a formative assessment.

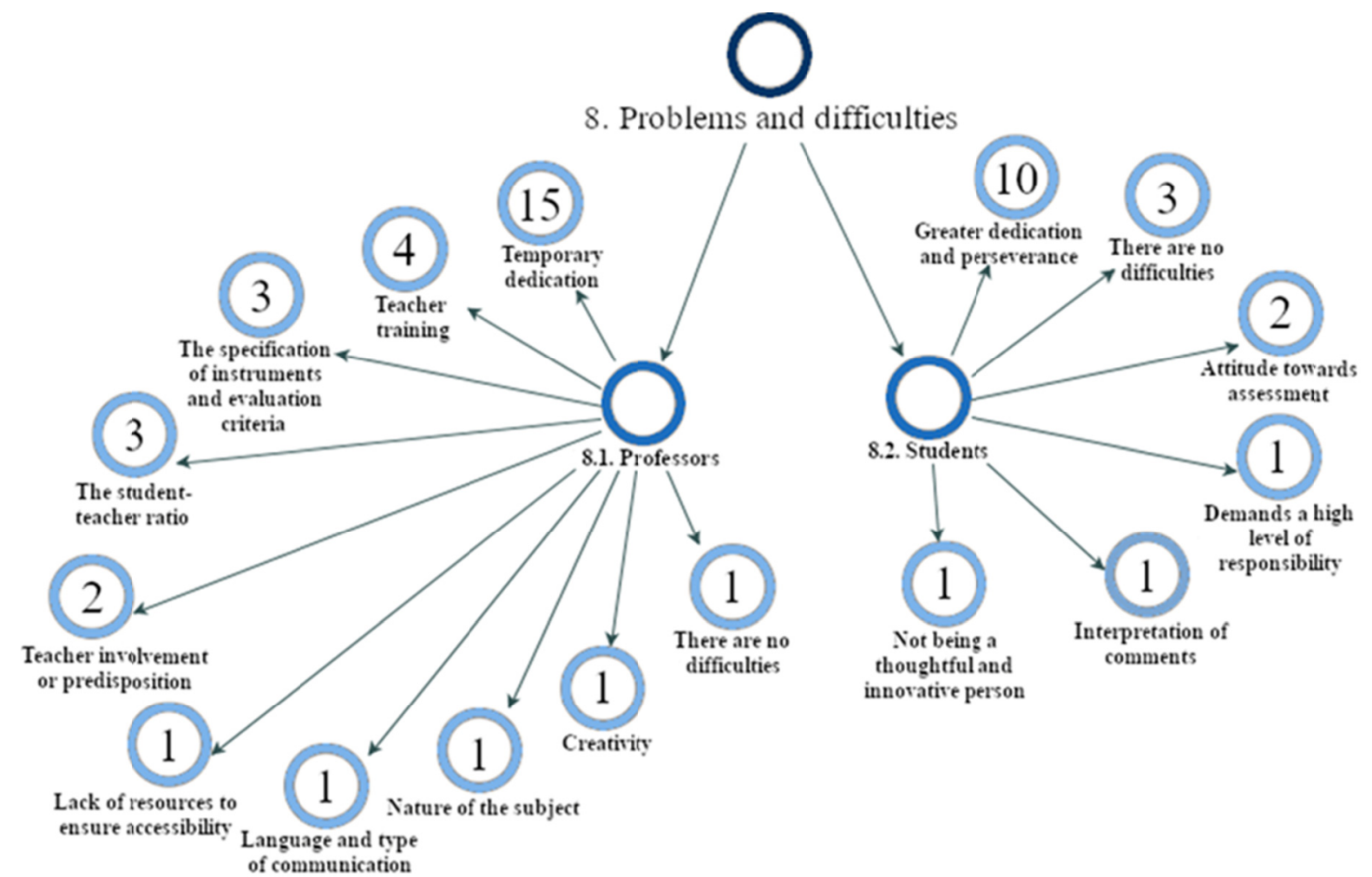

Figure 4. Map of difficulties associated with formative E-assessment for teachers and students

One of the hypotheses of this research was that there would be differences between the responses of the different master's degrees depending on their field of knowledge. However, the only inequalities which have been observed are concerning the presence of formative assessment in master's degrees and its frequency of use in each of the subjects that make up master's degrees.

By applying the cross searches between the codes of the different questions and the attributes associated with the cases, more relevant information associated with the teaching and coordination experience was found than with the fields of knowledge of each master's degree.

\section{Discussion and Conclusions}

Formative assessment is a widespread reality in universities (Cosi et al., 2020; Zhu et al., 2021). However, some virtual postgraduate studies do not include it in their academic programs or do not mention it as such (Aleyaasin, 2019; Llorca et al., 2015). From facts such as these, the research problem of the present work arises. This is, to analyse the use of formative evaluation in virtual official master's degrees taught in Spanish universities.

This type of assessment is one of the most recommended in virtual studies and demanded by students due to the lack of face-to-face contact (González, 2020). This data is corroborated in our research since most of the coordinators state that they use this type of assessment to offer feedback to their students and also as part of the final grade of the subjects. However, some fields such as Engineering and Architecture recognize that their master's degrees take this type of assessment into account, but not in all their subjects.

Generally, formative assessment has been theorized as an alternative that allows interaction with students and 
which improves their learning process (Chanpet et al., 2020; Hansen, 2020). However, according to the data provided by this research, it can be appreciated that this type of assessment is not only used to promote teacher-student interaction but that the results derived from formative E-assessment have an impact on the final grade received by each student.

Spanish online masters mainly use forums, the same student tasks, electronic messages and other digital tools of the official platform of the study program, thus coinciding with the results found by Colmenares (2012), and they show a clear preference for asynchronous tools. The use of synchronous tools could be an aspect to improve, as highlighted by Abate et al. (2021) in their research on the importance of synchrony in online teaching processes. Despite the extensive list of digital tools, the coordinators have not indicated the assessment strategies applied. Even though the questionnaire did explicitly ask about tools and strategies, none of the possibilities that exist was mentioned: role play, the minute paper, hook questions, things to keep in mind, questions walls, etc. (Bahati et al., 2019; Vonderwell \& Boboc, 2013).

Another possibility to carry out a formative assessment is to use the analytical data (descriptive statistics and/or learning analytics) produced by the digital platforms used. According to Barana et al. (2019), Karaoglan et al. (2020) and other authors, this is an ideal way to monitor students and can even lead to automatic evaluation. However, most coordinators acknowledge that the teachers in their master's degrees do not use these data or consult them. Only 6 coordinators stand out as taking this type of information into account, but not with the referenced objective, but to know the main problems of the students and thus avoid them dropping out of their studies. Furthermore, it has been identified that the coordinators who do take the learning statistics into account are those who have greater coordination experience. Therefore, it can be affirmed that it is an excellent possibility to complement the formative assessment. However, a certain background as a coordinator is needed.

The benefits associated with formative E-assessment in a university context are usually to monitor progress, promote motivation and improve the learning process, according to McCallum \& Milner (2020). This vision fully matches our results. The coordinators who have responded explain that in their opinion, this assessment modality demonstrates that it can improve the teaching and learning process, in addition to allowing better monitoring. It also appears that formative assessment increases satisfaction and motivation in students. The coordinators also point out benefits in terms of improving the autonomy and self-regulation of student learning, as well as facilitating the adaptation of teaching resources and methodologies to the individual needs of the students, thus promoting greater personalization of teaching (Fake \& Dabbagh, 2020).

On the one hand, the problems related to formative E-assessment appear to be mostly related to not adequately assessing the comments made by the teacher, focusing only on the grade, design of assessment instruments, or the amount of information generated (Irons, 2008; Webb et al., 2018). On the other hand, our research concludes that the most widespread problem -both for teachers and students- is the time involved in the development of formative assessment. For other authors, this is not the main problem (Hunt \& Pellegrino, 2002), so this answer may represent a peculiarity of the context studied (Spanish universities) and may open up interesting lines of research for the future. Mainly, because in the Spanish context temporary dedication to formative assessment has been identified as one of the most widespread difficulties in any educational initiative regardless of level (Aragonés et al., 2020; Cubero \& Ponce, 2020; Pineda et al., 2019).

Another difficulty observed by Irons (2008), the interpretation that the students make of the comments made by the teacher, hardly appears in our research, since only one coordinator in the field of Social and Legal Sciences has pointed it out.

Finally, contrary to the codes that list different difficulties for both teachers and students, there have been a small number of cases that think that there are no difficulties associated with formative assessment. Specifically, this idea is related more to the students than to the teachers.

About the limitations shown by the work carried out, the problems in being able to carry out the interview synchronously (by videoconference) should be emphasised. This possibility was rejected by almost all of the coordinators, who opted, as an alternative, to send the information in writing (using email). This change in design implies the absence of interactivity with the data-producing sample, an interaction that would have allowed us to examine the responses more profoundly. However, this alternative has allowed us to expand the participating sample and thus obtain a more complete approximation of the reality studied in terms of the number of cases.

As a future line of research based on this work, we propose to expand learning analytics as a complement to formative assessment, since it has been identified as one of the least used and known elements. This is considered of interest due to the current educational trend towards the automation of evaluation (Skalka \& Drlik, 2020; Tan et al., 2020; Wu \& Chang, 2020) or smart learning (Maulidiya et al., 2019; Nanning et al., 2020; Yusufu \& Nathan, 
2020), thus making these statistics an opportunity to enrich formative assessment and, therefore, to optimize the educational process.

We also believe that this research opens up interesting lines regarding the study of the use of synchronous tools since our data show that the orientation is mostly towards the use of asynchronous tools, thus coinciding with what generally occurs in online teaching (Laato \& Murtonen, 2020). And the experience developed in online degrees will be useful for students' assessment in general, especially because of all the changes and challenges in higher education in recent years caused by the pandemic (Ali \& Damour, 2021; Fatima et al., 2021; Peytcheva-Forsyth \& Aleksieva, 2021).

Finally, we believe that international comparative studies would help us understand why the time factor stands out as the main difficulty, while in other studies not appearing, as we have seen. We do not know if it is something typical of the Spanish context, or the reasons why this data appears so markedly in our research. We are also interested in approaching this study from the students' perspective, as their vision is essential to understand the real magnitude of the impact of this type of assessment. Thus, future research could investigate the impact of formative e-assessment concerning other topics like motivation or engagement to endorse the data found in this work about learning.

\section{Acknowledgements}

This work is part of the research project "Ecologies of learning in the digital age" (ECOLEARN-SE), partially funded by the Ministry of Science, Innovation and Universities (Reference RTI2018-09). All authors have read and agreed to the published version of the manuscript.

The authors are especially grateful for the collaboration of the master's degrees coordinators who kindly participated in this research.

\section{References}

Abate, A. F., Cascone, L., Nappi, M., Narducci, F., \& Passero, I. (2021). Attention monitoring for synchronous distance learning. Future Generation Computer Systems, 125, 774-784. https://doi.org/10.1016/j.future.2021.07.026

Aleyaasin, M. (2018). Digital assessment of individual engineering assignments in mass courses. Computer Applications in Engineering Education, 26(5), 1888-1893. https://doi.org/10.1002/cae.22014

Ali, L., \& Dmour, N. (2021). The Shift to Online Assessment Due to COVID-19: An Empirical Study of University Students, Behaviour and Performance, in the Region of UAE. International Journal of Information and Education Technology, 11(5), 220-228. https://doi.org/10.18178/ijiet.2021.11.5.1515

Alvira, F. (2011). La encuesta: Una perspectiva general metodológica. Madrid: Centro de Investigaciones sociológicas.

Aragonès, R., Tomé-Pires, C., López-Cortacans, G., Porta-Casteràs, D., Roigé-Castellví, J., Cardoner, N., Monreal, J.A., \& Palao, D. (2020). Curso de formación online para la implementación de un nuevo modelo de atención a la depresión en atención primaria. FEM. Revista de la Fundación Educación Médica, 23(3), 121-127. https://doi.org/10.33588/fem.233.1055

Azevedo, A., \& Azevedo. J. (2018). Handbook of research on E-Assessment in Higher Education. Pennsylvania: IGI Global. https://doi.org/10.4018/978-1-5225-5936-8

Babo, R., Rocha, J., Fitas, R. Suhonen, J., \& Tukiainen, M. (2021). Self and Peer E-Assessment: A Study on Software Usability. International Journal of Information and Communication Technology Education, 17(3), 68-85. http://doi.org/10.4018/IJICTE.20210701.oa5

Bahati, B., Fors, U., Hansen, P., Nouri, J., \& Mukama, E. (2019). Measuring learner satisfaction with formative e-assessment strategies. International Journal of emerging technologies in learning, 14(7), 61-79. https://doi.org/10.3991/ijet.v14i07.9120

Barana, A., Conte, A., Fissore, C., Marchisio, M., \& Rabellino, S. (2019). Learning analytics to improve formative assessment strategies. Journal of E-learning and knowledge society, 15(3), 75-88. https://doi.org/10.1016/c2015-0-00087-9

Cabero, J. (2017). La evaluación en la era digital. Madrid: Síntesis. Retrieved from http://bit.ly/2Ng8eTY

Chandrasekaran, S., Badwal, P., Thirunavukkarasu, G., \& Littlefair, G. (2016). Collaborative learning experience of students in distance education. In R. M. Lima, R. Graaff, A. C. Alves, A. Menezes, D. Mesquita, J. Dinis-Carvalho, L. Bettaieb, N. J. V. Hattum, N. B. M. M. Costa, R. M., Sousa, S. Fernandez, \& V. 
Villas-Boas (Eds.), Proceedings of the PAEE/ALE'2016, 8th International Symposium on Project Approaches in Engineering Education (PAEE) and 14th Active Learning in Engineering Education Workshop (ALE) (pp. 90-99). Universidade do Minho, Portugal. Retrieved from http://bit.ly/3agmtCa

Chanpet, P., Chomsuwan, K., \& Murphy, E. (2020). Online Project-Based Learning and Formative Assessment. Technology, Knowledge and Learning, 25(3), 685-705. https://doi.org/10.1007/s10758-018-9363-2

Colmenares, A. M. (2012). Los aprendizajes en entornos virtuales evaluados bajo la concepción formadora. Revista Electrónica Interuniversitaria de Formación del Profesorado, 15(1), 125-134. Retrieved from https://bit.ly/3deafKC

Cosi, S., Voltas, N., Lázaro-Cantabrana, J. L., Morales, P., Calvo, M., Molina, S., \& Quiroga, M. A. (2020). Formative assessment at university using digital technology tools. Profesorado, 24(1), 164-183. https://doi.org/10.30827/profesorado.v24i1.9314

Crocker, L., \& Algina, J. (1986). An introduction to classical and modern test theory. New York: Holt, Rinehart $\&$ Winston.

Cubero, J., \& Ponce, N. (2020). Aprendiendo a través de tareas de evaluación auténticas. Percepción de estudiantes de grado en Educación Infantil. Revista Iberoamericana de Evaluación Educativa, 13(1), 41-69. https://doi.org/10.15366/riee2020.13.1.002

Escobar-Pérez, J., \& Cuervo-Martínez, A. (2008). Validez de contenido y juicio de expertos: Una aproximación a su utilización. Avances en Medición, 6, 27-36.

Fake, H., \& Dabbagh, N. (2020). Personalized learning within online workforce learning environments: exploring implementations, obstacles, opportunities, and perspectives of workforce leaders. Technology, Knowledge and Learning, 25(4), 789-809. https://doi.org/10.1007/s10758-020-09441-x

González, V. (2020). El hundimiento de la evaluación online: una perspectiva de la situación actual. RIITE: Revista Interuniversitaria de Investigación en Tecnología Educativa, 8, 1-4. https://doi.org/10.6018/riite.430381

González-Sanmamed, M., Sangrá, A., Souto, A., \& Estévez, I. (2018). Ecologías de aprendizaje en la Era Digital: desafíos para la Educación Superior. Publicaciones, 48(1), 11-38. https://doi.org/10.30827/publicaciones.v48i1.7329

Hansen, G. (2020). Formative assessment as a collaborative act. Teachers' intention and students' experience: Two sides of the same coin, or? Studies in Educational Evaluation, 66, 100904. https://doi.org/10.1016/j.stueduc.2020.100904

Hasani, H., Khoshnoodifar, M., Khavandegar, A., Ahmadi, S., Alijani, S., Mobedi, A., ... \& Silbert, D. I. (2021). Comparison of electronic versus conventional assessment methods in ophthalmology resident: A learner assessment scholarship study. BMC Medical Education, 21(1), 1-9. https://doi.org/10.1186/s12909-021-02759-9

Hunt, E., \& Pellegrino, J.W. (2002). Issues, examples, and challenges in formative assessment. New directions for teaching and learning, 89, 73-85. https://doi.org/10.1002/t1.48

Irons, A. (2008). Enhancing learning through formative assessment and feedback. London: Rouutledge. https://doi.org/10.4324/9780203934333

Karaoglan, F. G., \& Yilmaz, R. (2020). Student opinions about personalized recommendation and feedback based on learning analytics. Technology, knowledge and learning, 25(4), 753-768. https://doi.org/10.1007/s10758-020-09460-8

Küppers, B., \& Schroeder, U. (2016). Bring your own device for e-assessment-A review. In L. Gómez, A. López, \& I. Candel (Eds.), EDULEARN16 Proceedings (pp. 8770-8776). IATED Academy. https://doi.org/10.21125/edulearn.2016.0919

Laato, S., \& Murtonen, M. (2020). Improving synchrony in small group asynchronous online discussions. Advances in Intelligent Systems and Computing, 1161, 215-224. https://doi.org/10.1007/978-3-030-45697-9_21

Lu, J., \& Law, N. (2012). Online peer assessment: effects of cognitive and affective feedback. Instructional Science, 40(2), 257-275. https://doi.org/10.1007/s11251-011-9177-2

Maulidiya, D., Santoso, H. B., \& Hasibuan, Z. A. (2019). A conceptual Multi-Dimensional Model for Smart 
Learning Environments. Proceedings of the 2019 International Conference on Advanced Computer Science and Information Systems (ICACSIS). IEEE. https://doi.org/10.1109/icacsis47736.2019.8979679

McCallum, S., \& Milner, M. M. (2020). The effectiveness of formative assessment: student views and staff reflections. Asessment \& Evaluation in Higher Education, 46(1). https://doi.org/10.1080/02602938.2020.1754761

McMillan, J. H., \& Schumancher, S. (2005). Investigación educativa (5th ed.). London: Pearson Educación. Retrieved from https://bit.ly/3esSybI

Mimirinis, M. (2019). Qualitative differences in academics' conceptions of e-assessment. Assessment and Evaluation in Higher Education, 44(2), 233-248. https://doi.org/10.1080/02602938.2018.1493087

Mosqueda, D.L. (2018). Uso de cuestionarios en Moodle para la autoevalua-ción de los conocimientos matemáticos. In J. Valverde (Ed.), Campus digitales en la educación superior (pp. 679-684). Servicio de publicaciones de la UEX, Extremadura. Retrieved from http://bit.ly/2FNqlgb

Nanning, Y., Donghua, W., Dandan, L., Qingqing, Z., Xiaoyan, W., Li, W., \& Haibin, W. (2020). The Status and Hotspots of Smart Learning: Base on the Bibliometric Analysis and Knowledge Mapping. Journal of Physics Conference Series, 1486, 032016. https://doi.org/10.1088/1742-6596/1486/3/032016

Peytcheva-Forsyth, R., \& Aleksieva, L. (2021). Forced introduction of e-assessment during COVID-19 pandemic: How did the students feel about that? (Sofia University case). AIP Conference Proceedings 2333, 050013. 1-11. https://doi.org/10.1063/5.0041862

Pineda-Herrero, P., Ciraso-Calí, A., \& Arnau-Sabatés, L. (2019). La FP dual desde la perspectiva del profesorado. Elementos que condicionan su implementación en los centros. Educación XX1, 22(1), 15-43. https://doi.org/10.5944/educxx1.21242

Prendes-Espinosa, M. P., Gutiérrez-Porlan, I., \& García-Tudela, P. A. (2021). Collaborative work in higher education: tools and strategies to implement the e-assessment. In R. Babo, N. Dey, \& A. S. Ashour (Eds.), Workgroups eAssessment: Planning, Implementing and Analysing Frameworks. Berlin: Springer. https://doi.org/10.1007/978-981-15-9908-8_3

Sánchez-Vera, M. M., Prendes-Espinosa, M. P., \& Fernández-Breis, J. T. (2013). Tecnologías semánticas para la evaluación en red: Análisis de una experiencia con la herramienta OeLE. RIE: Revista de Investigación Educativa, 31(2), 447-464. https://doi.org/10.6018/rie.31.2.116721

Sewell, J. P., Frith, K. H., \& Colvin, M. M. (2010). Online Assessment Strategies: a primer. Merlot, 6(1), 297-305. http://bit.ly/2uGVKP4

Sharma, D., \& Karforma, S. (2012). Risks and remedies in E-Learning System. International journal of network security \& its applications, 4(1), 51-59. https://doi.org/10.5121/ijnsa.2012.4105

Skalka, J., \& Drlik, M. (2020). Automated assessment and microlearning units as predictors of at-risk students and students'outcomes in the introductory programming courses. Applied Sciences, 10(13), 4566. https://doi.org/10.3390/app10134566

Tan, C., Han, R., Ye, R., \& Chen, K. (2020). Adaptive learning recommendation strategy based on Deep Q-Learning. Applied Psychological Measurement, 44(4), 251-266. https://doi.org/10.1177/0146621619858674

Webb, M. E., Prasse, D., Phillips, M., Kadijevich, D. M., Angeli, C., Strijker, A., ... Laugesen, H. (2018). Challenges for IT-Enabled formative assessment of complex 21 st century skills. Technology, knowledge and learning, 23, 441-456. https://doi.org/10.1007/s10758-018-9379-7

Wu, L. J., \& Chang, K. E. (2020). Effect of embedding a cognitive diagnosis into the adaptive dynamic assessment of spatial geometry learning. Interactive Learning Environments. https://doi.org/10.1080/10494820.2020.1815216

Wuisan, P. I., \& Wibawa, B. (2019). Using electronic assessment system in higher education: challenges and solutions for lectures, students and institutions. International journal of recent technology and engineering, 8(2), 673-678. https://doi.org/10.35940/ijrte.b1141.0982s919

Yusufu, G., \& Nathan, N. (2020). A novel model of smart education for the development of smart university system. Proceedings of the 2020 International Conference in Mathematics, Computer Engineering and Computer Science. IEEE. https://doi.org/10.1109/icmcecs47690.2020.240912 
Zhu, G., Raman, P., Xing, W., \& Slotta, J. (2021). Curriculum design for social, cognitive and emotional engagement in Knowledge Building. International Journal of Educational Technology in Higher Education, 18(1), 1-19. https://doi.org/10.1186/s41239-021-00276-9

Zwelijongile, B. (2015). Online formative assessment in higher education: Its pros and cons. Electronic Journal of e-Learning, 13(4), 228-236. Retrieved from https://bit.ly/37V5LYA

\section{Copyrights}

Copyright for this article is retained by the author(s), with first publication rights granted to the journal.

This is an open-access article distributed under the terms and conditions of the Creative Commons Attribution license (http://creativecommons.org/licenses/by/4.0/). 